\title{
GEREFORMEERDE TEOLOGIE IN DIE SPERVUUR TUSSEN FUNDAMENTALISME EN ANTI-FUNDAMENTALISME
}

G.J.C. Jordaan ${ }^{1}$

\author{
ABSTRACT \\ REFORMED THEOLOGY IN THE CROSSFIRE \\ BETWEEN FUNDAMENTALISM AND \\ ANTI-FUNDAMENTALISM
}

Reformed theology is often accused of harbouring fundamentalistic ideas, especially in its views regarding the authority and infallibility of Scripture, the validity of science, the nature of history and philosophical views on truth and reality. However, if compared to the reformed confessional writings, the ideas to which reformed theology subscribe, prove to be rooted in the reformed confession rather than in the concepts of fundamentalism. Although the reformed theology share a number of views with fundamentalism, there are equally a number of matters in which it differs from fundamentalism. Therefore the anti-fundamentalistic accusation against reformed theology proves to be mostly without a sound basis.

\section{INLEIDING}

In die hoofartikel van Die Kerkbode van 15 September 2000 word 'n baie interessante opmerking gemaak. Die redakteur van die blad maak beswaar teen die uitlating van prof. Christina Landman dat "in die godsdienstige pers net die stemme van 'n paar onderontwikkelde fundamentaliste" gepubliseer word. Hy vind haar uitlating nie net "onverstaanbaar" nie, maar ook "beledigend" (Anon 2000:6). Die interessante hieraan is die feit dat in Suid-Afrika dit tot nog toe hoofsaaklik die Gereformeerdes was aan wie die etiket van fundamentalisme gehang is, o.a. deur teoloë van die Hervormde en die Nederduits Gereformeerde Kerke (vgl. Loader 1980; Du Plessis 1991). Geen wonder dat Landman se opmerking soveel ontsteltenis by Die Kerkbode se redaksie ontlok het nie.

1 Prof. dr. G.J.C. Jordaan, Skool vir Bybelwetenskappe en Bybeltale, Fakulteit Teologie, Noordwes-Universiteit (voorheen P.U. vir C.H.O.); Posbus 20004, Noordbrug, 2522.

SBBGJCJ@puknet.puk.ac.za 
Dit blyk egter dat Gereformeerdes hulle die etiket van fundamentalisme ewe min laat welgeval. In die geledere van die Gereformeerde Kerk van SuidAfrika is fundamentalisme as sodanig nog altyd afgewys (vgl. Floor 1983: 15; Vergeer 1993:575). In Gereformeerde kringe word fundamentalisme beskou as ' $n$ beweging wat sulke eng en rigiede beskouings handhaaf dat dit saam met biblisme op die "teologiese spektrum" "regs" van die Gereformeerde teologie geposisioneer is (vgl. De Klerk 1937:19; Jordaan 1991:58). Maar met Landman se bewering blyk dat 'n situasie ontstaan het waar ook teologiese groeperinge "links" van die Gereformeerde teologie as fundamentalisties beskou word. Om sake verder te kompliseer, het 'n Gereformeerde teoloog self, by name M.A. Kruger, in 'n artikel in In die Skriflig (1993:583vv.) aangetoon dat daar inderdaad in die Gereformeerde teologie sekere trekke van fundamentalisme te bespeur is. Dit volg op 'n artikel van Gerrie Snyman (1992:363) waarin hy beweer dat daar binne die GKSA sekere groeperinge bestaan wat as fundamentalisties beskryf kan word en ander nie. Regs van die GKSA, links van die GKSA, binne die GKSA — waar word die fundamentalisme dan werklik aangetref?

Die antwoord op hierdie vraag hang waarskynlik af van watter definisie van fundamentalisme gevolg word. Hoe wyer en omvattender die definisie van die fundamentalisme is, hoe ' $\mathrm{n}$ groter deel van die teologie gaan onder die sambreel daarvan inpas. Die belangrike vraag is: Hoe moet fundamentalisme gedefinieer of getipeer word? Of liewer: Hoe wyd behoort dit gedefinieer te word? ' $n$ Te wye definisie kan immers daartoe lei dat bepaalde teologiese standpunte en aktiwiteite ten onregte as fundamentalisties bestempel kan word (Du Plessis 1991:210). In hierdie artikel word dan in die eerste plek besin oor 'n geldige definisie en wesenskenmerke van fundamentalisme. Hieraan word die Gereformeerde godsdiens en teologie dan opgeweeg, spesifiek deur die belydenisgrondslag waarop dit berus te vergelyk met die wesenskenmerke van die fundamentalisme.

\section{DEFINIËRING VAN FUNDAMENTALISME}

Die woord fundamentalisme het ' $n$ baie wye gebruiksveld. Dit word in die algemeen gebruik as verwysing na 'n houding van eng konserwatisme, vooroordeel en onwilligheid om eie standpunte te hersien (Barr 1981:3). Fundamentalisme is 'n algemene verskynsel wat nie tot die Christelike godsdiens en teologie beperk is nie, maar ook in ander godsdienste en op ander lewensterreine soos die politiek en die ekonomie aangetref word (Floor 1983:15; Kruger 1993:584). In hierdie artikel gaan dit spesifiek oor die verskynsel van fundamentalisme in die Christelike godsdiens en teologie. 
In Christelike konteks word die benaming fundamentalisme meesal teruggevoer na die Algemene Vergadering van die Presbiteriane in Amerika in 1910, waarby die volgende vyf punte as fundamenteel aanvaar is (Kruger 1993:585-6):

- $\quad$ die foutloosheid van die Skrif;

- $\quad$ die Godheid en onbevlekte ontvangenis van Christus;

- $\quad$ Christus se plaasvervangende versoening;

- $\quad$ die fisiese opstanding van Christus;

- die wederkoms van Christus.

J.N. Vorster (1988:156) toon egter aan dat hierdie punte deur feitlik alle Protestante aanvaar sou word en daarom so algemeen is dat dit nie as tipering van die fundamentalisme deug nie. Daarom sou 'n definiëring van fundamentalisme aan die hand van hierdie vyf punte beslis op 'n te wye definisie uitloop. Nogtans was die vyf fundamentele stellings van die Presbiteriane in 1910 die aansporing vir Curtis Lee Laws toe hy in 1920 sy toe antimodernistiese beweging die naam Fundamentalisme gegee het. Eers toe het die woord 'n negatiewe konnotasie begin kry.

In Suid-Afrika word fundamentalisme oor 'n breë kerklike spektrum angetref. Die tipies Amerikaanse fundamentalisme word merendeel in die meer charismatiese en pinkstergroeperings aangetref. In die Afrikaanse kerke lê die wortels daarvan eerder in die fundamentalisme van die Gereformeerde tradisie in Nederland (Loader 1980:101). Wanneer Loader na fundamentalistiese tendense en invloed binne die Gereformeerde teologie in SuidAfrika verwys, praat hy van "ortodokse fundamentalisme" (1980:101). Hierdie artikel se fokus is dan ook op hierdie "ortodokse fundamentalisme".

Verskeie skrywers het al probeer om fundamentalisme te definieer. J.N. Vorster (1993:15-16) sonder die volgende definisies uit:

- Furniss (1977:15) beskryf fundamentaliste as mense met 'n vrees vir die onbekende nuwe, wat hulle sekuriteit in die behoud van ou dinge soek en wat baie sterk oor hulle oortuigings voel. Aanklagte wat met hierdie definisie ooreenstem, word dikwels ook in die rigting van Gereformeerdes gemik. 'n Voorbeeld hiervan is Snyman (1992:355) se opmerking dat Gereformeerdes "tradisionele strukture" tot "geloofwaardigheidstrukture" verhef. Hy skryf (1992:356): "Dit is maklik om Gereformeerd te wees as die omgewing om jou ook Gereformeerd is." Loader rig sy kritiek op wat hy die "Totius-model van fundamentalisme" noem en beskryf dit as 'n denk-wêreld waarvoor "leefruimte gegee word deur 'maximal conservatism"' (Loader 1980:106). Vorster (1993:15) toon egter aan dat Furniss se definisie niks meer gee nie as 'n beskrywing van die 
psigologiese mondering van baie mense, selfs van absoluut uiteenlopende oortuigings. Daarom kan dit glad nie as definisie van die fundamentalisme deug nie.

- Niebuhr (vgl. Vorster 1993:15) tipeer fundamentaliste as mense wat uit minder intellektuele kringe (bv. die platteland) of uit die laer inkomstegroepe, kom. Christina Landman se uitlating waaroor Die Kerkbode so beledig voel, waarin sy na "onderontwikkelde fundamentaliste" verwys, sluit duidelik by Niebuhr se definisie aan. Weer eens is dit egter' $n$ onhoudbare definisie, aangesien die sogenaamde fundamentalisme beslis ook sterk in gegoede en intellektuele groepe voorkom (Vorster 1993:16). Ook Barr (1981:91) wys enige poging om fundamentalisme aan mense uit 'n bepaalde sosiale of opvoedkundige sfeer toe te skryf, beslis af.

Teen die agtergrond van minder geslaagde definisies soos dié hierbo, is Loader van mening dat 'n oorvereenvoudigde definisie van fundamentalisme liewer vermy moet word (1980:101). Du Plessis (1991:201) sluit hierby aan en wys daarop dat fundamentalisme moeilik definieerbaar is omdat dit nie ' $n$ bestaande geslote ideologie is nie. Dit is ' $n$ verskynsel wat hoofsaaklik kenbaar is aan enkele basiese kenmerke wat op verskillende plekke en tye in die geskiedenis na vore getree het. In aansluiting by Vorster (1933:16) fokus hierdie artikel dan verder op bepaalde kenmerke aan die hand waarvan fundamentalisme beskryf word.

Sandeen (1970:5) noem fundamentalisme 'n beweging wat in die Amerikaanse pre-millennialisme en in die teologie van Princeton van die 1930's gewortel is. Hiermee beskryf hy fundamentalisme volgens sy historiese agtergrond en aan die hand van 'n bepaalde standpunt, nl. pre-millennialisme. In aansluiting hierby beskryf (Marsden 1980:2) fundamentalisme as 'n losse koalisie tussen strominge soos die Amerikaanse herlewingsbewegings, $\mathrm{Pu}$ ritanisme, piëtisme, evangeliebewegings ("evangelicals"), millennialisme en Baptistiese tradisionalisme wat kragte saamsnoer in reaksie op die modernistiese teologie. Barr (1981:1) gee waarskynlik die duidelikste omskrywing van die basiese kenmerke van fundamentalisme. Volgens hom is fundamentalisme 'n religieuse houding in konserwatiewe kringe wat die volgende kenmerke vertoon:

- $\quad$ Dit lê klem op die foutloosheid van die Bybel.

- Dit staan negatief teenoor die modernistiese teologie en die wetenskap.

- Dit is sterk eksklusiwisties.

Vorster (1993:16) sluit by Barr se beskrywing aan en voeg die volgende kenmerke daarby: 
- $\quad$ Fundamentalisme vertoon 'n onderontwikkelde historiese bewussyn.

- $\quad$ Dit berus op die filosofie van Scottish Common Sense Realism.

- Dit maak gebruik van grammaties-historiese eksegese.

Bogenoemde beskrywings is kennelik gerig op die Amerikaanse fundamentalisme. Hoewel sekere van hierdie standpunte beslis in die Suid-Afrikaanse fundamentalisme aangetref word, bied dit nog nie 'n werklik tiperende beskrywing van wat Loader "ortodokse fundamentalisme" noem nie. Vir die raakste tipering kan die beskrywing van Vorster (1993) oorweeg word. Volgens hom is die wesenskenmerk van fundamentalisme dat dit die Bybel as absolute gesagsbron gebruik (Vorster 1993:17). Hierdie wesenskenmerk is eie nie net aan die "ortodokse fundamentalisme" in Suid-Afrika nie, maar aan fundamentalisme wêreldwyd. Barr (1984:13) sê dat fundamentalisme die Christendom sien as "a scripturally controlled religion", 'n beskouing wat volgens hom teen die gegewens van die Nuwe Testament indruis. Volgens Barr beskryf die Nuwe Testament Jesus as iemand met "a rather free attitude to Scripture" en moet die kerk vandag dieselfde houding as Jesus inneem (1984:13). Wells (1980:33-39) toon egter aan dat Barr met uitsprake soos hierdie in 'n sirkel-argument beland, aangesien hy die standpunt teen "a Scripturally controlled religion" juis na analogie van die Skrif self poneer.

Desnieteenstaande bring Vorster en Barr se beskrywing van fundamentalisme vir Gereformeerdes 'n belangrike vraag na vore: As die gebruik van die Bybel as absolute gesagsbron dan tipies van die fundamentalisme is, hoe verskil die fundamentalisme dan van die Gereformeerde belydenis? In artikel 5 van die Nederlandse Geloofsbelydenis (NGB) bely die kerke van die Reformasie immers duidelik dat ons die ses-en-sestig boeke van die Bybel as kanoniek aanvaar "om ons geloof daarna te rig, daarop te grondves en daarmee te vestig." Getuig hierdie belydenis dan nie van 'n geloof wat deur die Skrif bepaal word nie? Ook in artikel 7 bely ons:

Ons glo dat hierdie Heilige Skrif die wil van God volkome bevat en dat alles wat die mens vir sy saligheid moet glo, daarin voldoende geleer word.

Sê dit nie dat die Bybel as absolute gesagsbron erken word nie?

Barr (1984) spreek egter beswaar uit teen enige bewering dat "fundamentalism properly represents the faith of the Reformation" (1984:155). Volgens hom is fundamentalisme maar slegs één afstammeling van die Reformasie, aangesien ook "liberal Protestantism" wettiglik van die Reformasie afstam. Toegepas op die "ortodokse fundamentalisme" in Suid-Afrika, verdien hierdie bewerings van Barr in twee opsigte kommentaar. 
- $\quad$ Eerstens moet dit duidelik gestel word dat fundamentalisme (ook "ortodokse fundamentalisme") 'n etiket is wat in Suid-Afrika aan Gerformeerdes toegeken word en nie 'n staanplek is wat self gekies is nie. Die Gereformeerde teologie wil homself stel op die grondslag van die Bybel, volgens die gereformeerde belydenisskrifte se samevatting ("interpretasie", aldus Barr 1984:149), ongeag wat in fundamentalisme daarvan gemaak word. 'n Geldige toets vir die Gereformeerde teologie is dus om in die eerste plek te vra tot watter mate dit met die gereformeerde belydenisskrifte korreleer.

- Tweedens blyk dit dat Barr met sy opmerking ook 'n soortgelyke staanplek vir wat hy liberale Protestantisme noem, opeis. Dit is beslis sy goeie reg. Dit beteken egter dat ook hierdie liberale Protestantisme aan dieselfde toets as die Gereformeerde teologie onderwerp moet word, naamlik die vraag na die mate waarin dit getrou aan sy belydenisgrondslag is.

In aansluiting by bogenoemde vrae bied hierdie artikel 'n toegespitse vergelyking tussen die kenmerke wat an fundamentalisme toegeskryf word en die Gereformeerde belydenisskrifte. Waar toepaslik, word die kenmerke ook geplaas teen die agtergrond van die Reformasie. Met die vergelyking word ook die ander kenmerke wat aan fundamentalisme toegeskryf word, aan die orde gestel.

\section{3. 'N VERGELYKING MET DIE BELYDENIS- SKRIFTE}

\subsection{Historiese bewussyn}

Volgens Vorster (1993:19) word die fundamentalisme gekenmerk deur wat hy noem 'n onderontwikkelde historiese bewussyn. Teenoor die Darwinisme staan die fundamentalisme daarop dat niks natuurlik, insidenteel of toevallig ontwikkel nie (vgl. ook Barr 1981:97-98). Die geskiedenis word supranatureel bestuur. Dit lei tot die vraag: Is hierdie beskouing van die geskiedenis werklik tipies aan die fundamentalisme of kan dit teruggevoer word na die gereformeerde belydenisskrifte?

Die geskiedenis word in Sondag 10 van die Heidelbergse Kategismus (HK) gestel binne die voorsienigheid van God:

waardeur Hy hemel en aarde en al die skepsels asof met sy hand nog onderhou en so regeer dat ... alles ons nie per toeval nie maar uit sy vaderhand toekom. 
... aangesien alle skepsels só in sy hand is dat hulle hulle sonder sy wil nie kan roer of beweeg nie.

Waar kom die Kategismus aan hierdie beskouing? Aangesien die Kategismus uit die 16e eeu dateer kon dit uiteraard nie gestaan het onder invloed van 'n reaksiebeweging teen Darwinisme of selfs die 17e-eeuse historisme nie. Getrou aan sy bedoeling spreek die Kategismus bloot die Skrif na. Bewys daarvan is die talle Skrifbewyse by Sondag 10 - iets wat volgens Vorster ook tipies fundamentalisties is (1993:21).

Vorster toon aan dat die geskiedenisbeskouing van die fundamentalisme dikwels gewortel is in die dispensasieleer van die millennialisme, wat voortspruit uit 'n baie letterlike verstaan van Openbaring 20 en Daniël 9 (Vorster 1993:20-21). Die millennialisme figureer natuurlik nie in die gereformeerde belydenisskrifte nie, en, hoewel dit wel in Gereformeerde geledere voorkom, word dit merendeels in charismatiese kringe aangehang. Miskien kan 'n saak daarvoor uitgemaak word dat die geskiedsbeskouing van die chiliasme sterk fundamentalistiese trekke vertoon. Veral 'n fatalistiese geskiedsbeskouing wat dikwels as deel van die leer van die millennialisme aangebied word (vgl. Vorster 1993:21), het waarskynlik 'n fundamentalistiese ondertoon. Dit vorm nie deel van die gereformeerde belydenis nie, net so min as wat enige evolusionistiese denkbeeld wat die geskiedenis of dele daarvan aan toeval toeskryf en buite God se voorsienigheid plaas, met die gereformeerde belydenis te rym is.

Daarteenoor is ' $n$ beskrywing van die geskiedenis as dat dit volkome binne die voorsienigheid van God verloop, in volkome ooreenstemming met die gereformeerde belydenis. Om so 'n geskiedenisbeskouing aan die invloed van fundamentalisme toe te skryf, soos Vorster (1994:19) doen, is daarom nie verantwoordbaar nie.

\subsection{Afwysend teenoor die wetenskap}

Vorster (1993:23) beweer dat dit kenmerkend is van fundamentalisme dat dit afwysend staan teenoor die wetenskap. Barr (1981:91) maak dit egter duidelik dat hierdie bewering nie ongekwalifiseerd gemaak kan word nie. Baie fundamentaliste is immers toegewyde wetenskaplikes. Hulle stel egter wetenskap ondergeskik aan geloof (1981:92). Ook Vorster gee toe dat baie fundamentaliste juis 'n hoë premie op die wetenskap en die intellek plaas. Maar dan gaan dit oor 'n eiesoortige intellektualisme waarin die idee van 'n objektiewe waarheid en objektiwiteit in die wetenskap aangehang word (Vorster 1993:23). 
Om Barr se opmerkings aan die belydenisskrifte te meet, is nie maklik nie, aangesien die belydenisskrifte geen direkte uitspraak oor die verhouding tussen geloof en wetenskap maak nie. Wel moet daarop gewys word dat in artikel 2 van die Nederlandse Geloofsbelydenis (NGB) bely word dat die onsigbare dinge van God "deur middel van die skepping, onderhouding en regering van die hele wêreld" duidelik sigbaar vir alle mense gestel word. "Soos 'n mooi boek waarin alle skepsels, groot en klein, die letters is" kan en moet gelowiges die skepping bestudeer ten einde God se ewige krag en goddelikheid des te beter te leer ken. Hiermee word wetenskap en geloof nie teenoor mekaar gestel nie. Ook word dit nie naas mekaar gestel of die een bo die ander gestel nie. Wetenskap en geloof word aan mekaar verbind op so 'n wyse dat van gelowige wetenskapsbeoefening gepraat moet word. Daarmee word gesê dat die gelowige, terwyl hy wetenskaplik besig is, dit deurentyd doen vanuit die geloofsoortuiging dat in dit wat hy bestudeer, hy iets van die onsigbare dinge van God, van sy ewige krag en goddelikheid, kan raaksien.

Die neiging om wetenskap en geloof teenoor mekaar te stel of om, soos Barr (1981:91-92) beweer, wetenskap ondergeskik aan geloof te stel deur die geloof bloot wetenskaplike resultate te laat "veto", het egter geen aanwysbare grond in die gereformeerde belydenisskrifte nie. So 'n beskouing van geloof en wetenskap sou waarskynlik wel na een of ander vorm van fundamentalisme teruggevoer kon word.

Ook Vorster (1993:23) se bewering dat die idee van 'n objektiewe waarheid en objektiwiteit in die wetenskap aan fundamentalisme toegeskryf moet word, moet geweeg word. Wat die tweede deel van die bewering betref, naamlik dat fundamentalisme objektiwiteit in die wetenskap nastreef, kan gesê word dat die skoen nie die gereformeerde teologie pas nie. Hoewel die gereformeerde belydenisskrifte nie direk oor die verhouding tussen geloof en wetenskap praat nie, het Gereformeerdes nog altyd sterk standpunt ingeneem teen die idee van objektiwiteit in die wetenskap, veral in soverre dit neutrale wetenskap suggereer (Floor 1984:12²). Juis die feit dat die gereformeerde godsdiens, soos hierbo aangedui is, 'n hoë premie op gelowige wetenskapbeoefening plaas, staan lynreg teenoor die idee van objektiwiteit in die wetenskap.

Die gedagte van 'n objektiewe waarheid, daarenteen, blyk inherent aan die gereformeerde belydenis te wees. Hoewel elke artikel van die NGB begin

2 Floor (1984:36-37) maak 'n geldige en toepaslike onderskeid tussen gelowige wetenskap (d.i. beoefening van wetenskap vanuit Christelike geloofsoortuiging) en wetenskapsgeloof (d.i. geloof in die wetenskap en in die outonomie van die wetenskap). 
met "Ons glo ... ", wil dit nie sê dat dit 'n subjektiewe waarheid verwoord nie. Inteendeel, wanneer in die heel eerste artikel bely word "dat daar 'n enige en enkelvoudige geestelike Wese is wat ons God noem", sê dit per implikasie dat God buite die mens om as objektiewe werklikheid bestaan. Ook die middele waaruit God kenbaar is, is buite die mens geleë, bely artikel 2, naamlik die skepping en die Goddelike woord. In artikel 7 word die Goddelike Skrif "die waarheid van God" genoem en word uitdruklik bely dat "dié waarheid bo alles" is. Die bron van waarheid is dus buite die mens geleë. Ja, ons waarneming daarvan is subjektief, maar God openbaar die waarheid oor Homself buite die mens om - objektief. Daarom is die idee dat waarheid iets is wat objektief buite die mens bestaan, inherent aan die gereformeerde belydenis en kan dit nie as sodanig aan fundamentalisme verbind word nie.

\subsection{Filosofiese grondslag}

Vorster se hoofpunt van kritiek teen fundamentalisme is die filosofiese grondslag waarop dit berus (1993:23-31). Vorster gee toe dat fundamentaliste nooit direk na hulle filosofiese grondslag verwys nie. Tog wys hy die Scottish Common Sense Realism van die $18 \mathrm{e} \mathrm{eeu}^{3}$ uit as die eintlike filosofiese grondslag van die fundamentalisme, hoewel hy van mening is dat fundamentaliste nie daarvan bewus is dat hulle denke op hierdie filosofie berus nie (1993:24).

Die Scottish Common Sense Realism stel die werklikheid primêr - en nie die idee (soos die filosofie van Idealisme dit wil hê) nie. Volgens die Common Sense Realism bestaan die werklikheid onafhanklik van die idees van mense. Dit is dus 'n objektiewe werklikheid en nie, soos die Idealisme beweer, 'n projeksie van menslike idees nie.

Met die beskouing van 'n objektiewe werklikheid kan die gereformeerde godsdiens en teologie grootliks akkoord gaan, nie om filosofiese redes nie, maar soos hierbo in 3.2 aangetoon is, op grond van die gerefomeerde belydenis. Nie die Scottish Common Sense Realism nie, maar die reformatore van die 16e eeu, by name Calvyn, het die gereformeerde godsdiens in hierdie waarheidsbeskouing voorgegaan. Talle plekke in Calvyn se Institusie sou in hierdie verband uitgewys kon word. As voorbeeld kan verwys word na wat Calvyn na aanleiding van Johannes 14:94 in sy Institusie (4.8.5) skryf:

3 Belangrikste eksponente van die "Scottish Common Sense Realism" was Thomas Reid (1710-1796), Dugald Stewart (1753-1828), James Beattie (1753-1803), James Oswald (1715-1769), Thomas Brown (1778-1820) en William Hamilton (1788-1856).

4 Johannes 14:9: "Wie My gesien het, het die Vader gesien." 
Hoe sou hulle (d.i. die gelowiges) die geheimenisse van God òf met hulle verstand kon begryp het, òf kon uitspreek as Hy ... hulle dit nie geleer het nie? Die heiliges het God derhalwe slegs leer ken wanneer hulle Hom in die Seun soos in 'n spieël waargeneem het.

En van die Ou-Testamentiese gelowiges skryf hy verderaan:

Hulle kinders en kleinkinders het inderdaad geweet dat dit wat hulle gehoor het uit die hemel en nie uit die aarde nie afkomstig was ...

Uit die staanspoor het die gereformeerde teologie dus die Skrif so verstaan dat dit God se getuienis van Homself is - nie 'n projeksie van ons eie menslike idees nie, maar 'n openbaring wat van buite onsself (d.i. objektief), van God af, kom. Ook in Artikel 7 van die NGB word dan 'n duidelike onderskeid getref tussen geskrifte van mense en die Goddelike Skrif en word bely dat geen menslike geskrifte met die Goddelike Skrif gelykgestel mag word nie.

Vorster verbind die fundamentalisme egter ook met die Scottish Common Sense Realism se waarnemingsleer (1993:26vv.). Hiervolgens het die mens in homself die verstandelike vermoë of natuurlike oordele ("common sense") om die werklikheid objektief waar te neem en te evalueer. Indien fundamentalisme wel hierdie aspek van die Common Sense Realism sou onderskryf, kan dit nie van die gereformeerde teologie gesê word nie. Die gereformeerde godsdiens bely juis die verdorwe natuur van die mens (HK So. 3) waardeur hy in sy oordele swak en stompsinnig geword het (vgl. NGB art. 33). Weer eens kan na Calvyn verwys word (vgl. bespreking na aanleiding van Matteus 8:19, 20 in Institusie, 4.8.8):

En omdat hulle (die dissipels) die dinge wat hulle uit die mond van die Meester gehoor en geleer het, vanweë hulle stompsinnigheid nie kon begryp nie, word die Gees van waarheid aan hulle beloof sodat hulle daardeur tot ware kennis van alle dinge gelei kan word.

Anders as die filosofie van die Common Sense Realism aanvaar die gereformeerde teologie nie dat die mens in staat is om objektief waar te neem of te oordeel nie. Deur die Heilige Gees word die mens se subjektiewe oordeel egter vernuwe en deur die Gees en die Woord na die objektiewe geopenbaarde waarheid van God gelei (HK So. 3; Dordtse Leerreëls 3/4:16).

\subsection{Eksklusiwisties}

Volgens Barr (1981:1) is fundamentalisme kenbaar aan 'n sterk eksklusiwisme. Vorster (1993:31) verwys daarna as 'n absolutistiese religieuse houding. Vir albei gaan dit oor die eis om getrouheid aan die belydenis en die gevolg- 
like leertug. Omdat fundamentaliste 'n absolute waarheid voorstaan, is almal wat buite daardie waarheid staan, volgens hulle uitgesluit van die saligheid (Barr 1984:155).

Leertug as sodanig kan egter nie as 'n tipies fundamentalistiese neiging gesien word nie, aangesien die gereformeerde belydenis leertug uitdruklik as bevel van Christus bely. As voorbeeld dien Sondag 31 van die HK waarin bely word dat "dié wat die naam Christen dra en tog 'n onchristelike leer huldig" ná vermaning daarin bly volhard, "uit die Christelike gemeente en deur God self uit die ryk van Christus uitgesluit" sal word. Dat leertug toegepas moet word, is dus nie bloot 'n fundamentalistiese verskynsel nie.

Kruger (1993:591) is daarom van mening dat 'n bepaalde vorm van leertug by die fundamentalisme voorkom, naamlik dat iemand afgesny of afgewys word sonder om eers "deur die volle gang van die tug" vas te stel of iemand 'n ware gelowige is of nie. So 'n wyse van tughandeling sou neerkom op 'n liefdelose onverhoorde veroordeling en kom inderdaad nie met die gereformeerde belydenis ooreen nie. Sondag 31 van die HK noem immers duidelik dat afsnyding eers voorafgegaan moet word deur herhaalde broederlike vermaning. Kruger staaf sy bewering dat liefdelose tughandeling eie aan die fundamentalisme is, nie oortuigend nie. Die enkele voorbeelde van liefdeloosheid en onverdraagsaamheid binne gereformeerde geledere wat hy aantoon, is nog geen bewys van fundamentalisme nie. Trouens, liefdeloosheid en onverdraagsaamheid is 'n houding wat eie aan alle sondaarmense is en wat in alle religieuse groeperinge voorkom en aangetoon kan word.

Barr (1994:155vv.) se kritiek op fundamentaliste is egter dat hulle hulle eie interpretasie van die Bybel tot absolute waarheid verhef en diegene wat nie met hulle interpretasie saamstem nie, van die Christelike kerk wil uitsluit. In dié sin word fundamentalisme as eksklusiwisties en imperialisties bestempel (Vorster 1993:38). Almal moet soos húlle glo, of hulle is uit. Hierdie beswaar kan teruggevoer word na die filosofiese grondslag van die skrywers se waarheidsbeskouing. Waar 'n relasionele waarheidsbeskouing aangehang word, is daar natuurlik geen basis op grond waarvan leertug toegepas kan word nie. Binne so 'n beskouing kan een leer nie bo 'n ander gestel word as sou dit beter met die waarheid korreleer nie, want daar bestaan nie so iets soos 'n vaste, objektiewe waarheid nie. Die HK se besliste onderskeid tussen 'n christelike en 'n onchristelike leer (So. 31) asook artikel 29 van die NGB se onderskeid tussen die ware kerk en die valse kerk skakel so 'n relasionele beskouing binne die gereformeerde teologie egter by voorbaat uit.

Nogtans, ten spyte van die sterk gereformeerde standpunt oor leersuiwerheid, is daar in die gereformeerde tradisie nooit so ver gegaan om te sê dat diegene wat buite die gereformeerde leer staan, daarom verlore gaan nie. 
Calvyn se genaakbaarheid in hierdie opsig is bekend, naamlik dat hy nie bereid was om te sê dat almal wat nog in die Roomse kerk is, verlore gaan nie. Die rede hiervoor is eenvoudig dat die kerk, al moet hy dwaalleer uitwys en afwys, nie oor die mens se hart kan oordeel nie (de intimis ecclesia non iudicat). Hierdie genaakbaarheid gee egter nie aanleiding tot onverskilligheid nie. Juis uit liefde vir die ware leer en vir die naaste word in artikel 30 NGB bepaal dat elke kerkraad "moet sorg dra dat die ware godsdiens onderhou en die ware leer oral versprei" word.

\subsection{Skrifbeskouing}

Wanneer oor Skrifbeskouing gehandel word, kom die kern van die sogenaamde "ortodokse fundamentalisme" onder die loep, aangesien, aldus Vorster (1993), 'n wesenskenmerk van fundamentalisme is dat dit "die Bybel as absolute gesagsbron gebruik" (1993:17). Hierbo in afdeling 2 van hierdie artikel is reeds aangetoon dat die gebruik van die Bybel as absolute gesagsbron die grondslag van die gereformeerde belydenisskrifte uitmaak en nie bloot aan fundamentalisme toegeskryf kan word nie. Die erkenning van die Bybel as gesagsbron hang egter ten nouste saam met Skrifbeskouing as geheel.

In aansluiting by Barr (1981:72-84) beskryf Vorster die Skrifbeskouing wat in fundamentalisme gehandhaaf word, soos volg (1993:50vv.):

- Die Bybel is die (verbaal) geïnspireerde Woord van God;

- Daarom is dit foutloos;

- Die Bybel is 'n "stoorkamer" van feite oor alles en nog wat.

\subsection{1 (Verbaal) geïnspireerde Woord van God?}

Die siening dat die Bybel die geïnspireerde Woord van God is, het egter nie fundamentalistiese oorsprong nie. In artikel 3 van die NGB word, na aanleiding van 2 Petrus 1:21 bely dat die woord van God

nie deur die wil van 'n mens gestuur of voortgebring is nie, maar die heilige mense van God het dit, deur die Heilige Gees gedrywe, gespreek.

Weliswaar word hier nog nie van die geskrewe Woord van God gepraat nie, maar net in die volgende sin word bely dat God sy knegte beveel het "om sy geopenbaarde Woord op skrif te stel." Daarmee word bevestig dat die Goddelike inspirasie ook vir die geskrewe Woord van God geld. Hierin spreek die gereformeerde belydenis die Skrif na, by name 2 Timoteus 3:16, waar die teopneustie van die hele Skrif geleer word (vgl. Ridderbos 1968:64). 
Barr (1984:124-130) beweer dat hierdie Skrifdele hoegenaamd nie as bewyse van die inspirasie van die (hele) Bybel gebruik kan word nie, omdat die Bybel nie destyds reeds ' $n$ afgeslote eenheid was nie en eers later op inisiatief van die kerk tot stand gekom het. Wells (1980:173-174) toon egter aan dat Barr se standpunt berus op ' $n$ voorveronderstelling dat daar nie ' $n$ onderlinge eenheid tussen die Bybelboeke bestaan nie omdat die boeke vir Barr per definisie menslike produkte was.

Op die bewering dat fundamentaliste, en daarom ook Gereformeerdes, 'n verbale inspirasieleer van die Bybel handhaaf, is dit belangrik om duidelikheid te kry oor wat met "verbale inspirasie" bedoel word. Vir die geykte beskouing van verbale inspirasie as 'n proses waarin die Heilige Gees as't ware die Bybelboeke woord vir woord vir die Bybelskrywers gedikteer het (vgl. Trimp 1992:124), word daar in die gereformeerde belydenis nie voorsiening gemaak nie. In artikel 3 van die NGB word immers niks meer gesê nie as dat

God deur sy besondere sorg vir ons en ons saligheid sy knegte (die profete en apostels) beveel het om sy geopenbaarde Woord op skrif te stel.

Calvyn word dikwels daarvan beskuldig dat hy die idee van 'n verbale Skrifinspirasie onderskryf het. Hy het immers na die Bybelskrywers verwys as "sekretarisse van die Heilige Gees" (vgl. Graafland 1993:78). Uit Calvyn se kommentare is dit egter duidelik dat hy nie daarmee bedoel het dat die Heilige Gees woord vir woord gedikteer en dat die Bybelskrywers maar klakkeloos neergeskryf het nie. Veel eerder moet dit verstaan word dat, net soos 'n goeie sekretaris wel sy eie woorde gebruik en tog nie sy eie besluite notuleer nie maar steeds dié van die vergadering, die Bybelskrywers ook hulle eie woorde gebruik het maar steeds neergeskryf het wat die Heilige Gees wou hê. Calvyn se "verbale inspirasieleer" het dus 'n baie sterk ooreenkoms vertoon met wat hedendaags die "organiese inspirasieleer" genoem word (Graafland 1993:79).

So maklik is dit egter nie om ons van fundamentalisme te distansieer nie. Vorster sê met nadruk dat fundamentaliste weier om hulleself as aanhangers van 'n verbale inspirasieteorie te sien (1993:60). Maar al weier hulle om dit te erken, sê hy, hang hulle in werklikheid tog 'n verbale inspirasieteorie aan (1993:60). Wanneer Vorster dan die fundamentaliste se argumente en bewysvoering ter ondersteuning van hulle inspirasieleer weergee, is dit feitlik woordeliks die argumente wat vir die gereformeerde organiese inspirasieleer gebruik word. Dit is asof Vorster sê: die gereformeerde inspirasieleer is in sy wese fundamentalisties. 
Watter inspirasieleer sou dan wel met die gereformeerde belydenis klop? Vanuit die "liberale Protestantisme" sou 'n verskeidenheid van uiteenlopende antwoorde voorsien kon word, byvoorbeeld die gedeeltelike of die aktuele inspirasieteorieë (Roberts 1978:23). Waarskynlik die duidelikste antwoord kom egter uit die pen van James Barr self (1984), wat as selfverklaarde liberale Protestant en tegelyk een van die felste kritici van fundamentalisme die Bybel sien as 'n bundel boeke wat bloot op inisiatief van die vroeë kerk tot stand gekom het (1984:19). Dit is met ander woorde die produk van gemeenteteologie. Barr beskou die Bybel nie as 'n onfeilbare boek nie maar as 'n boek vol foute en weersprekende teologiese insigte van verskillende skrywers (1984:129). Daarom besit die Bybel volgens hom ook nie onweerspreekbare gesag nie. Watter waarde het die Bybel dan wel? Barr (1984:129) antwoord:

The Bible remains a substantially reliable document of the world of ancient Israel and of the early decades of the church.

Dit blyk dus dat Barr grootliks 'n godsdiens-historiese beskouing van die Skrifgesag aanhang. Sy standpunt vertoon egter geen ooreenkoms met die NGB se belydenis dat die Bybel "die heilige en Goddelike Skrif" is wat "God deur sy besondere sorg vir ons" laat opteken het nie (NGB art. 3).

\subsubsection{Foutloosheid, onfeilbaarheid en skopus}

Die fundamentalisme se siening van die foutloosheid van die Bybel, soos Vorster (1993) dit beskrywe, kom daarop neer dat die historiese, geografiese en selfs natuurwetenskaplike gegewens in die Bybel in elke opsig foutloos is (1993: 53). In die gereformeerde teologie word die Bybel egter nie as foutloos nie maar as absoluut onfeilbaar erken. Daarmee word gesê dat die Bybel die volkome onfeilbare openbaring is van alles wat God daarin aan ons wil bekend maak (d.w.s. in sy skopus), hoewel dit, sonder om sy onfeilbaarheid prys te gee, tog oneffenhede oor byvoorbeeld historiese en geografiese gegewens bevat (vgl. Coetzee 1995:34). Fundamentaliste wil egter niks weet van sulke oneffenhede nie. In fundamentalisme word die onfeilbaarheid van die Bybel immers aan foutloosheid verbind, tot so 'n mate dat die betroubaarheid van die Bybel vir hulle daarby staan en val (vgl. Barr 1981:62).

Dit blyk dus dat die fundamentalistiese Skrifbeskouing in hierdie opsig nie met die Gereformeerde siening ooreenstem nie. Die Gereformeerde beskouing van onfeilbaarheid van die Skrif is egter in navolging van die NGB, waarin bely word dat daar teen die kanonieke boeke "niks ingebring kan word nie" (art. 4) en: "Ons verwerp ... met ons hele hart alles wat nie met hierdie onfeilbare reël ooreenkom nie" (art. 7). Waaroor praat die kanonieke 
boeke dan so met onfeilbare gesag? Met hierdie vraag kom die kwessie van die skopus van God se Skrifopenbaring aan die orde.

Volgens Vorster (1988) hanteer fundamentalisme die Bybel asof dit 'n "stoorkamer" van feite oor alles en nog wat is. Elke Bybelse gegewene, hetsy grammaties, histories, wetenskaplik, geografies, kultureel of godsdienstig, staan volgens die fundamentalisme op dieselfde feitelike basis (1988:162). So ' $n$ beskouing word egter nie deur die gereformeerde belydenis gerugsteun nie. In artikels 2 tot 7 van die NGB word daar telkens verwys na die doel, oftewel die skopus waarmee God sy Woord vir ons op Skrif laat stel het. In artikel 5 word bely dat ons die kanonieke boeke aanvaar "om ons geloof daarna te rig, daarop te grondves en daarmee te bevestig." Daarteenoor kan die apokriewe boeke nie met dieselfde krag en gesag "enigiets van die geloof of van die Christelike godsdiens" leer nie. Daarmee word oor die algemeen reeds aangedui dat die kanonieke boeke van die Bybel gerig is op geloof en godsdiens. In die ander NGB-geloofsartikels word dié skopus soos volg verbesonder:

- Die eer van God: In sy Woord maak God aan ons bekend "so veel as wat vir ons in hierdie lewe nodig is tot sy eer ..." (art. 2).

- Die wil van God: "Ons glo dat hierdie Heilige Skrif die wil van God volkome bevat ..." (art. 7).

- Die weg tot saligheid: In sy Woord maak God aan ons bekend "so veel as wat vir ons in hierdie lewe nodig is ... tot die saligheid van bulle wat aan Hom behoort" (art. 2). "Ons glo ... dat alles wat die mens vir sy saligheid moet glo, daarin voldoende geleer word" (art. 7).

In navolging van hierdie geloofsartikels handhaaf die gereformeerde teologie die Bybel as onfeilbare openbaring van alles wat ons moet glo tot die eer van God, tot ons saligheid en ook ter nakoming van sy wil (vgl. Coetzee 1995:32-33). Op foutlose inligting oor allerhande ander angeleenthede, soos fundamentalisme wil hê, maak nóg die belydenisskrifte nóg die Bybel self enige aanspraak. Ook in hierdie opsig doen die gereformeerde teologie dus afstand van die denkbeelde van die fundamentalisme.

\subsection{Skrifgebruik}

In die laaste plek het Vorster dit oor die Skrifgebruik van die fundamentalisme. Die grammaties-historiese Skrifgebruik, sê hy, is tipies fundamentalisties (1993:67). Want dit veronderstel 'n verbaal-geïnspireerde Bybel, waarvan die betekenis in die teks geleë is en nie daaragter nie. Dit veronderstel dat 'n mens die betekenis van die teks kan vasstel en op vandag kan toepas. Dit veronderstel verder dat die Bybel duidelik, deursigtig en ver- 
staanbaar is vir almal wat dit lees, juis omdat dit letterlik verstaan word, behalwe waar dit self aanduiding gee dat dit figuurlik of simbolies verstaan wil word (Vorster 1993:67).

Hierdie wyse van Skrifhantering is egter nie deur die fundamentalisme ontwerp nie, maar word reeds net so by Calvyn aangetref (vgl. Floor 1980: 18-19) en gaan trouens nog verder terug, tot by die grammaties-historiese benadering van die Antiocheense skool in die vyfde eeu. Om grammatieshistoriese Skrifgebruik as fundamentalisties af te maak, grens dus aan 'n anachronisme.

Verder sê Vorster (1993:64) dat die praktyk van Skrif-met-Skrif-vergelyking direk in verband staan met die fundamentalisme se siening van die Bybel as betroubaar en foutloos. Hy beskryf die fundamentalistiese standpunt soos volg:

Die taak van die eksegeet is om hierdie feite (vanoor die hele Bybel) met mekaar in verband te bring en daarom kan ook die Fundamentaliste hul aanslag onder die ou gereformeerde banier loods as 'n beweging wat die reformasie wil voortsit, en vergelyk hulle ook Skrif met Skrif (1993:64).

Weliswaar handel die gereformeerde belydenisskrifte nêrens oor die Bybelse hermeneutiek nie. Eksegetiese praktyke soos grammaties-historiese eksegese en Skrif-met-Skrif-vergelyking word ook nêrens in die belydenisskrifte vermeld nie. Tog word die beginsels waarop hierdie praktyke berus - beginsels soos die gesag van die Skrif, sy deursigtigheid, sy eenheid en sy onfeilbaarheid - direk in artikels 2 tot 7 van die NGB bely. Die oorsprong van hierdie eksegetiese praktyke is nie in die fundamentalisme geleë nie maar in die gereformeerde belydenis. Weliswaar word hierdie praktyke dan ook beoefen, nie onder die banier van fundamentalisme nie, maar, soos Vorster (1993:64) dit stel, "onder die ou gereformeerde banier".

\section{KONKLUSIE}

Uit bostaande karakterisering is dit duidelik dat baie van dit wat in die moderne teologie as denkbeelde van die fundamentalisme afgewys word, in werklikheid eg gereformeerde standpunte is wat duidelik in die gereformeerde belydenisskrifte teruggevind kan word. Dit sluit in die gereformeerde siening van

- God se voorsienigheid en sy beheer oor die geskiedenis;

- die erkenning van 'n objektiewe werklikheid wat buite die mens bestaan; 
- die beskouing van die Bybel as betroubare, gesagvolle, geïnspireerde Woord van God;

- die taak van die kerk om die suiwere leer te verdedig en te verkondig en om alle dwaalleer te bestry;

- die grammaties-historiese Skrifverklaring en die eksegetiese praktyk van Skrif-met-Skrif-vergelyking.

Hoewel die fundamentalisme bostaande beskouings tot ' $\mathrm{n}$ groot mate met die gereformeerde godsdiens en teologie deel, is daar tog bepaalde fundamentalistiese kenmerke wat hoegenaamd nie aan die gereformeerde teologie verbind kan word nie. Dit is die volgende:

- Die feit dat die fundamentalisme in sy wese 'n "anti"-karakter het (al kom die gereformeerde teologie saam met die fundamentalisme teen die modernisme te staan);

- 'n Byna fatalistiese geskiedsbeskouing, waarby die millennialisme met sy dispensasieleer inpas;

- 'n Vertroue op die vermoë van die mens om rasioneel tot objektiewe kennis van die werklikheid te kom (en daarmee saam aanhanklikheid aan die Scottish Common Sense Realism);

- Vyandigheid jeens die wetenskap wat in sommige fundamentalistiese kringe voorkom;

- 'n Eksklusiewe houding waarvolgens andersdenkende Christene as ongelowiges beskou word wat verlore gaan;

- Die handhawing van die foutloosheid van die Bybel.

Hierdie standpunte staan nie net teenoor die beskouings wat in die gereformeerde teologie gehandhaaf word nie; dit wyk ook af van die gereformeerde belydenis soos verwoord word in die Drie Formuliere van Eenheid.

\section{TEN SLOTTE}

Om die gereformeerde teologie onder dieselfde sambreel as die fundamentalisme tuis te bring, is dus onverantwoordbaar. Tog verwag kritici per implikasie van Gereformeerdes om te breek met alles wat enigsins met fundamentalisme in verband gebring kan word, en om ander denkbeelde te aanvaar (vgl. Snyman 1992:363; Kruger 1993:598-600; Loader 1980:114-117). Die persepsie wat geskep word, is dat Gereformeerdes, solank as hulle bereid is om standpunte en metodes met die fundamentalisme te deel, in wese fundamentalisties en onwetenskaplik is (vgl. Snyman 1992:363). 
Hierdie "eis" skep egter baie sterk die indruk van 'n "anti"-houding, waarskynlik 'n vorm van anti-fundamentalisme. Net soos die fundamentalisme van anti-modernisme beskuldig word, kan fundamentalisme se kritici van anti-fundamentalisme verdink word. Hierdie twee faksies laat geen ruimte vir mekaar nie en betoon ook nie genade aan mekaar nie (vgl. Barr 1984:149155). En tussen die twee vyandige linies, staan die gereformeerde teologie. Aan die een kant anti-modernisme en aan die ander kant anti-fundamentalisme. Die fundamentalisme roep (byna militant) weg uit die geledere van die modernisme; die modernisme roep (ewe militant) weg uit die geledere van die fundamentalisme. Beide faksies is ewe eksklusiwisties: As jy nie by ons staan nie, sê die fundamentaliste, is jy buite die kring van die ware gelowiges. As jy nie by óns staan nie, sê die moderniste, is jy buite die kring van die ware wetenskaplikes. Omgekeerd, sê die anti-modernis: jy kan nie 'n gelowige wees as jy 'n modernis is nie; en die anti-fundamentalis sê: as jy 'n fundamentalis is, is jy onwetenskaplik. Natuurlik is beide hierdie "anti"argumente drogargumente. Nóg kan slegs fundamentaliste op die ware geloof aanspraak maak, nóg kan die modernisme alleen op wetenskaplikheid aanspraak maak.

Vir Gereformeerdes is dit moeilik om hulle met die denkbeelde enige van die twee faksies te vereenselwig. In werklikheid kom Gereformeerdes nie by een van die groeperinge tuis nie. Gereformeerdes het in die spervuur tussen die twee strydende groepe te staan gekom - onvermydelik, want ons bevind ons op dieselfde slagveld. Albei faksies roep ons om na hulle toe oor te stap. Van die posisie waar hulle staan, lyk dit vir albei faksies of ons by hulle opponente tuishoort. Daarom word ons vanuit fundamentalistiese geledere beskuldig van modernisme en vanuit modernistiese geledere van fundamentalisme.

So word fundamentalisme en modernisme moeilik definieerbare verskynsels en loop dit gevaar om bloot etikette te word waarmee diegene wat nie met jou saamstem nie, swartgesmeer word. Vir die fundamentalis is almal wat "links" van hom staan per definisie modernisties en liberaal; vir die modernis is alles "regs" van hom fundamentalisties. Hoe verder links op die spektrum jy dan staan, hoe meer fundamentaliste is daar na jou oordeel. En omgekeerd. Daarom gebeur dit dat Christina Landman skrywers in Die Kerkbode as fundamentalisties bestempel. 


\title{
BIBLIOGRAFIE
}

\author{
ANONIEM \\ 2000. Praat voordat jy dink. Die Kerkbode 165(6) 15 September:6. \\ BARR J \\ 1981. Fundamentalism. Londen: SCM. \\ 1984. Beyond Fundamentalism. Philadelphia: Westminster.

\section{CALVYN J} \\ 1992 [1559]. Institusie van die Christelike godsdiens. Boek 4. Uit Latyn vertaal \\ deur H.W. Simpson. Potchefstroom: CJBF.

\section{De KLeRK B J} \\ 1937. Vorme en karakter van die Biblisisme. Kampen: Kok. \\ Du Plessis P J
} 1991. Fundamentalism as methodological principle. In: P.J. Hartin \& J.H. Petzer (eds.), Text and Interpretation (Leiden: Brill), pp. 201-213.

\section{FLOOR L}

1980. Die hermeneutiek van Calvyn. In die Skriflig 14(55):13-20.

1983. Fundamentalisme: vanwaar die aanklag? Goue Kandelaar, 22:15-17.

1984. Die Skrif en wetenskap. In: Wetenskap en woord: 'n bundel voordragte saamgestel deur die Departement Wetenskapsleer. Wetenskaplike bydraes van die PU vir CHO (Reeks J: Potchefstroomse studies in Christelike wetenskap. Reeks J1), pp.1-14.

\section{FURNISS N}

1977. The case for the welfare state: from social security to social equality. Bloomington: Indiana University Press.

\section{GRAAFLAND C} 1993. "Honderd jaar theologie" in de Gereformeerde Kerken. Gereformeerd Theologisch Tijdschrift 1993:77-87.

\section{KRUGER M A}

1993. 'n Weg uit die oorheersing van die histories-kritiese metode, fundamentalisme en genitiefteologieë. In die Skriflig 27(4):583-602.

LOADER J A 1980. Ortodokse fundamentalisme en die gebruik van die Ou Testament in Suid-Afrika. Hervormde Teologiese Studies 35:101-118.

\section{MARSDEN GM}

1980. Fundamentalism and American culture. Oxford: Oxford University Press.

\section{RIDDERBOS H N}

1968. Het Woord, het Rijk en onze verlegenheid. Kampen: Kok. 


\section{ROBERTS J H}

1978. Inleiding tot die studie van die Nuwe Testament — Prinsipiële gesigspunte en terreinverkenning. In: A.B. du Toit (red.), Handleiding by die Nuwe Testament. Band 1 (Pretoria: N.G. Kerkboekhandel), pp. 1-50.

\section{SANDEEN E R}

1970. The roots of Fundamentalism. Chicago: University Press.

\section{SNYMAN G}

1992. Binnegevegte in die GKSA: verskuiwing van 'plausibility structures'? In die Skriflig 26(3):351-367.

\section{TRIMP C}

1992. Heilige Geest en Heilige Schrift. In: J. Kamphuis, W. van 't Spijker, C. Trimp \& W.H. Velema (reds.), Hoe staan wij ervoor? (Barneveld: Vuurbraak), pp. 103-137.

\section{VEERGEER W}

1993. Teologie en kenteorie: 'n Reaksie op die artikels van Gerrie Snyman. In die Skriflig 27(4):563-582.

\section{VORSTER J N}

1988. The use of Scripture in fundamentalism. In: J. Mouton, A.G. van Aarde \& W.S. Vorster (reds.), Paradigms and progress (Pretoria: HRSC), pp. 155-175. 1993. Die Fundamentalisme. Bybelkunde Studiebrief 102/1993. Pretoria: Unisa.

Trefwoorde

Fundamentalisme

Skrifgesag

Onfeilbaarheid

Anti-fundamentalisme

Modernisme
Keywords

Fundamentalism

Authority of Scripture

Infalliblity

Anti-fundamentalism

Modernism 